\title{
DAMPAK GLOBALISASI TERHADAP MORALITAS REMAJA ( Studi SMK Swasta Putra Bunda Tanjung Pura) Tahun Pelajaran 2018/2019
}

\author{
Dedi Hermawan \\ STKIP Budidaya Binjai
}

\begin{abstract}
ABSTRAK
Globalisasi adalah kecenderungan umum terintegrasinya kehidupan masyarakat domestik/lokal ke dalam komunitas global di berbagai bidang. Akibat adanya era globalisasi membawa pengaruh kepada seluruh aspek, baik dari segi Pendidikan, Ekonomi, Sosial, IPTEK, bahkan moral anak remaja pun mengalami perubahan. Hal yang sangat mengguncangkan bagi seluruh negara adalah masalah perekonomian. Tetapi di indonesia tidak hanya itu, krisis moral anak remajapun sangat memprihatinkan. Moral atau perilaku anak remaja di indonesia mengalami perubahan karena adanya pengaruh dari negara luar yang dibawa ke indonesia. Itu semua langsung diserap begitu saja tanpa memikirkan atau memilih perilaku yang seharusnya di ambil oleh anak remaja di indonesia. Dahulu, moral anak indonesia bisa diacungkan jempol. Dilihat dari tatakramanya, sopan santun dan tutur bahasanya yang baik. Tetapi kini, moral atau perilaku anak remaja di indonesia sangat memprihatinkan. Di Indonesia masalah tersebut dirasa telah mencapai tingkat yang cukup meresahkan bagi masyarakat. Kondisi ini memberikan dorongan yang kuat pada pihak-pihak yang bertanggung jawab, seperti kelompok edukatif di lingkungan sekolah, sekelompok hakim dan jaksa di bidang penyuluhan dan penegak kehidupan. Demikian juga pemerintah sebagai bentuk kebijakan umum dan pembinaan, penciptaan dan pemeliharaan keamanan dan ketertiban masyarakat, faktor lain yang tidak dapat dikesampingkan pula adalah masyarakat dan keluarga.Konsep diri suatu hal yang tidak dibawa sejak lahir dan berkembang melalui pendidikan serta interaksi individu dengan orang-orang di lingkungannya. Oleh karena itu, konsep diri seseorang dengan orang lain tidaklah sama, hal ini juga berlaku pada mahasiswa yang berprofesi sebagai pelaku intelektual.
\end{abstract}

Kata kunci : globalisasi, moralitas

\section{PENDAHULUAN}

Globalisasi adalah kecenderungan umum terintegrasinya kehidupan masyarakat domestik/lokal ke dalam komunitas global di berbagai bidang. Akibat adanya Era Globalisasi membawa pengaruh kepada seluruh aspek, baik dari segi Pendidikan, Ekonomi, Sosial, IPTEK, bahkan moral anak remaja pun mengalami perubahan. Hal yang sangat mengguncangkan bagi seluruh Negara adalah masalah perekonomian. 
Tetapi di Indonesia tidak hanya itu, krisis moral anak remajapun sangat memperhatinkan. Moral atau perilaku anak remaja di indonesia mengalami perubahan karena adanya pengaruh dari Negara luar yang dibawa ke Indonesia. Itu semua langsung di serap begitu saja tanpa memikirkan atau memilih perilaku yang seharusnya diambil oleh anak remaja di Indonesia. Dahulu, moral anak Indonesia bisa diancungkan jempol. Dilihat dari tata kramanya, sopan santun dan tutur bahasanya yang baik. Tetapi kini, moral atau prilaku anak remaja di Indonesia sangat memprihatinkan.

Maju mundurnya suatu bangsa mendatang juga terletak dipundak generasi muda. Diambang pintu kedewasaan menanti tugas-tugas yang harus mereka penuhi, maka bekal-bekal tertentu sangat perlu dipersiapkan bagi mereka. Hal ini seperti yang dikatakan oleh Winarno Surakhmad (1980:11) Suatu fakta didalam sejarah perkembangan umat yang memelihara kelangsungan hidupnya untuk senantiasa menyerahkan, mempercayakan hidupnya ditangan generasi yang lebih muda.

Karakter bangsa juga merupakan aspek penting terhadap kualitas Sumber Daya Manusia, karena kualitas karakter bangsa menentukan kemajuan suatu bangsa. Karakter yang berkualitas perlu untuk dibentuk dan dibina sejak usia dini. Dimana usia dini merupakan fase kritis bagi pembentukan karakter seseorang. Menurut Freud dalam Masnur Muslich, (2011:35) "kegagalan penanaman kepribadian yang baik di usia dini akan membentuk pribadi yang bermasalah dimasa dewasanya kelak". Banyak sekali perilaku-perilaku menyimpang yang kian marak terjadi di Indonesia. Penyimpangan-penyimpangan tersebut sebagian besar dilakukan atau dialami oleh anak remaja. Penyimpangan yang dilakukan biasanya seperti, free sex, narkoba, dan lain-lain.

Sementara itu, di dalam kebijakan nasional, antara lain ditegaskan bahwa pembangunan karakter bangsa merupakan kebutuhan asasi dalam berbangsa dan bernegara. Sejak awal kemerdekaan, bangsa Indonesia sudah bertekad untuk menjadikan pembangunan karakter bangsa sebagai lahan penting dan tidak dipisahkan dari pembangunan nasional. Muchlas Samani \& Hariyanto (2012:26) Menyatakan "Lebih lanjut perlu diingat bahwa secara eksplisit pendidikan 
karakter adalah amanat UndangUndang No 23 Tahun pasal 3 tentang Sistem Pendidikan Nasional, yang menegaskan bahwa : Pendidikan Nasional berfungsi mengembangkan kemampuan dan membentuk watak serta peradaban bangsa yang bermartabat dalam rangka mencerdaskan kehidupan bangsa, bertujuan untuk berkembangnya potensi peserta didik agar menjadi manusia yang beriman dan bertakwa kepada Tuhan Yang Maha Esa, berakhlak mulia, sehat, berilmu, cakap, , kreatif, mandiri, dan menjadi warga negara yang demokratis serta bertanggung jawab".

Globalisasi pada dasarnya dapat membawa dampak positif dan negatif secara bersamaan. Dampak globalisasi yang paling terasa dapat terjadi dalam beberapa aspek yaitu aspek politik, ekonomi dan sosial-budaya. Dalam aspek politik, dampak positifnya adalah adanya pemerintahan yang terbuka dan demokratis, sedangkan dampak negatif yang dapat terjadi adalah adanya liberalisme yang memungkinkan adanya perubahan ideologi bangsa.

Dalam aspek ekonomi, dampak positifnya adalah terbukanya pasar internasional sehingga memungkinkan meningkatkan kesempatan kerja dan meningkatkan devisa negara, sedangkan dampak negatifnya adalah hilangnya rasa cinta terhadap produk dalam negeri karena banyak produk luar negeri yang diperjual bebas di Indonesia.

Dalam penelitian ini dirumuskan masalah yakni sebagai berikut : 1).Apa defenisi dari globalisasi?. 2).Bagaimana dampak globalisasi terhadap moralitas remaja?. 3).Bagaimana peran guru PPKn dalam menanamkan unsur moralitas remaja akibat globalisasi?

Tujuan dari peneliti adalah : 1).Untuk mengetahui defenisi dari globalisasi. 2).Untuk mengetahui dampak globalisasi terhadap moralitas remaja. 3).Untuk mengetahui peran guru PPKn dalam menanamkan unsur moralitas remaja akibat globalisasi. 


\section{METODE}

Jenis penelitian ini adalah penelitian kualitatif dengan menggunakan analisis deskriptif yaitu penelitian yang dilakukan untuk memperoleh gambaran situasi dan kejadian-kejadian secara kongkret tentang keadaan obyek atau masalah. Penelitian ini akan dilakukan di SMK Swasta Putra Bunda berlokasi di jalan sepakat/suka jadi dusun VI pekubuan Kecamatan PekanTanjung Pura.

Waktu penelitian ini dilaksanakan dari bulan januari sampai September. Teknik pengumpulan data berupa 1).Observasi, 2).Wawancara, 3).Dokumentasi. Dalam menganalisis data dalam pembinaan nilai moralitas peserta didik menggunakan analisis kualitatif.

\section{HASIL PENELITIAN DAN PEMBAHASAN}

\section{Hasil}

Penelitian ini dilaksanakan di SMK Swasta Putra Bunda Berlokasi di Jalan Sepakat/suka jadi dusun VI pekubuan Kecamatan Pekan Tanjung Pura. Pengamatan kondisi awal dilaksanakan untuk mengetahui keadaan nyata di lapangan sebelum peneliti melaksanakan proses penelitian. Proses penelitian ini dilaksanakan dalam 3 tahap yang masing-masing terdiri dari yaitu, 1). Observasi, 2). Wawancara, 3). Dokumentasi Dalam penelitian ini yang dijadikan sebagai subjek adalah Remaja. Sementara yang menjadi objek dari penelitian ini adalah Dampak Globalisasi Terhadap Moralitas.

Hasil wawancara tersebut dengan siswa - siswi SMK SWASTA PUTRA BUNDA TANJUNG PURA sebagai narasumber ada beberapa siswa - siswi yang mengerti mengenai Globalisasi mengenai dampak positif dan negatif tentang Globalisasi. Namun ada beberapa siswa - siswi yang tidak mengerti dan tidak paham mengenai Globalisasi sehingga peneliti memberikan pemahaman kepada siswa-siswa tersebut mengenai dampak positif dan negatif mengenai Globalisasi. Hasil dari wawancara terhadap guru, sebagai narasumber, mengenai Dampak Globalisasi Terhadap Moralitas Remaja. Guru sangat berperan penting dalam menyikapi Globalisasi terhadap moral siswa - siswi SMK SWASTA PUTRA BUNDA TANJUNG PURA. 


\section{Pembahasan Hasil Penelitian}

Proses globalisasi lahir dari adanya perkembangan ilmu pengetahuan, teknologi transportasi dan komunikasi. Globalisasi akan memberikan corak budaya baru, dan memberi dampak yang luas terhadap kebebasan budaya setempat dan mengukuhkan domisi budaya barat dalma budaya masyarakat di negara-negara berkembang melalui penjajahan baru, yaitu kebudayaan.

Bagaimanapun itu harus kita cegah karena kebudayaan bangsa merupakan hasil peninggalan nenek moyang bangsa kita yang harus kita jaga dan kita lestarikan. Salah satu penyebab terjadinya era globalisasi adalah kemajuan ilmu pengetahuan dan teknologi terutama teknologi komunikasi, seperti teknologi media cetak dan media elektronik.

\section{SIMPULAN}

Berdasarkan hasil penelitian dan pembahasan yang telah diuraikan pada bab sebelumnya, maka dapat diambil kesimpulan sebagai berikut :1). Kehadiran globalisasi tentunya membawa pengaruh bagi siswa - siswi Smk Swasta Putra Bunda Tanjung Pura. Globalisasi mempunyai pengaruh yang positif dan juga pengaruh negatif. Pengaruh-pengaruh tersebut tidak secara langsung berpengaruh terhadap nasionalisme. Namun secara keseluruhan dapat menimbulkan rasa nasionalisme terhadap bangsa menjadi berkurang atau bahkan hilang.2). Dampak positif bagi Siswa-Siswi Smk Swasta Putra Bunda Tanjung Pura terhadap adanya globalisasi adalah Adanya globalisasi menyebabkan pergeseran nilai dan sikap siswa-siswa yang semula irasional menjadi rasional; berkembangnya ilmu pengetahuan dan teknologi yang membuat siswa-siswi menjadi lebih mudah dalam beraktivitas dan mendorong untuk berpikir lebih maju. 3). Sedangkan dampak negatif dari adanya globalisasi diantaranya : Globalisasi mampu meyakinkan Remaja Indonesia bahwa liberalisme dapat membawa kemajuan dan kemakmuran; hilangnya rasa cinta terhadap produk dalam negeri karena banyaknya produk luar negeri; Remaja lupa akan identitas diri sebagai bangsa Indonesia karena gaya hidupnya cenderung meniru budaya barat; sikap 
individualistik yang menimbulkan ketidakpedulian antarperilaku sesama warga; serta kesenjangan sosial.

\section{REFERENSI}

Haricahyono, Cheppy. 1995. Dimensi-Dimensi Pendidikan Moral. Semarang: IKIP Semarang Press.

Komarudin Hidayat dan Azyumardi Azra,MA, Pendidikan Kewarganegaraan, (Jakarta: ICCE UIN Syarif Hidayatullah).

Kun Maryati dan Juju Suryawati, Sosiologi,(Jakarta:2007, PT.Gelora Askara Pratama).

Liyanarachi, G. (2009). The Impact of Moral Reasoning and Retaliation on WhistleBlowing: New-Zealand Evidence. Journal of Business Ethics 89.

Masnur Muslich, Pendidikan Karakter Menjawab Tantangan Krisis Multidimensional, (Jakarta : Bumi Aksara.2011).

Muchlas Samani \& Hariyanto, Konsep dan Model Pendidikan Karakter, (Bandung:PT REMAJA ROSDAKARYA.2012).

Sudarsono, Etika Islam Tentang Kenakalan Remaja, (Jakarta: PT Rineka Cipta, 1991), Cet.ke-2, h. 2W.J.S. Poerwadarminta, Kamus Umum Bahasa Indonesia, Balai Pustaka, Jakarta, 1986, cet. IX.

Winarno Surakhmad, Psikologi Pemuda, (Bandung: Jemmars, 1980), Cet.ke-2. 